\title{
Prostaglandin Transporter Modulates Wound Healing in Diabetes by Regulating Prostaglandin-Induced Angiogenesis
}

\author{
Mahrukh M. Syeda, ${ }^{\star}$ Xiaohong Jing, ${ }^{\dagger}$ \\ Raihan H. Mirza, ${ }^{*}$ Hong Yu, ${ }^{*}$ Rani S. Sellers, ${ }^{\neq}$ \\ and Yuling Chi* \\ From the Departments of Medicine* and Pathology, ${ }^{*}$ Albert \\ Einstein College of Medicine, New York City; and the \\ Computational Biology Center, ${ }^{\dagger}$ Memorial Sloan Kettering Cancer \\ Center, New York City, New York
}

Prostaglandin transporter (PGT) mediates prostaglandin (PG) catabolism and PG signal termination. The prostanoid $\mathrm{PGE}_{2}$, which induces angiogenesis and vasodilation, is diminished in diabetic skin, suggesting that PGT up-regulation could be important in wound healing deficiency, typified by diabetic foot ulcer. We hypothesized that up-regulation of PGT in hyperglycemia could contribute to weakened $\mathrm{PGE}_{2}$ signaling, leading to impaired angiogenesis and wound healing. In human dermal microvascular endothelial cells (HDMECs), exposure to hyperglycemia increased PGT expression and activity up to threefold, accompanied by reduced levels of $\mathrm{PGE}_{2}$. Hyperglycemia reduced HDMEC migration by $\mathbf{5 0} \%$ and abolished tube formation. Deficits in $\mathrm{PGE}_{2}$ expression, HDMEC migration, and tube formation could be corrected by treatment with the PGT inhibitor T26A, consistent with the idea that PGT hyperactivity is responsible for impairments in angiogenesis mediated by PG signaling. In vivo, PGT expression was profoundly induced in diabetes and by wounding, correlating with diminished levels of proangiogenic factors $\mathrm{PGE}_{2}$ and VEGF in cutaneous wounds of diabetic mice. Pharmacological inhibition of PGT corrected these deficits. PGT inhibition shortened cutaneous wound closure time in diabetic mice from 22 to 16 days. This effect was associated with increased proliferation, re-epithelialization, neovascularization, and blood flow. These data provide evidence that hyperglycemia enhances PGT expression and activity, leading to diminished angiogenic signaling, a possible key mechanism underlying defective wound healing in diabetes. (Am J Patbol 2012, 181: 334-346; bttp://dx.doi.org/10.1016/j.ajpath.2012.03.012)
Diabetic foot ulcer (DFU), a significant complication in diabetes, is difficult to treat, has a high frequency of recurrence, and often leads to amputation. ${ }^{1}$ It is estimated that, worldwide, more than one million people with diabetes require limb amputation each year, a rate of one major amputation every 30 seconds. ${ }^{2}$ Despite widespread incidence and significant consequences, the therapies for treating DFU and the efficacy of those therapies are limited, ${ }^{3-5}$ in part because the etiology of DFU is complex and not well understood.

DFU is classified as either ischemic or neuropathic, and is caused by defects in endothelial and peripheral vascular function ${ }^{6-8}$ induced by hyperglycemia. ${ }^{9}$ Endothelial and peripheral vascular functions are mediated by multiple molecular factors, including prostaglandins (PGs). ${ }^{10} \mathrm{PGE}_{2}$ and $\mathrm{PGI}_{2}$ are vasodilators, maintaining the balanced vascular pressure, patency, and perfusion required to maintain blood flow to peripheral tissues. ${ }^{11-14}$ They also stimulate angiogenesis by inducing vascular endothelial growth factor (VEGF). ${ }^{15-18}$ Angiogenesis is essential for wound healing, ${ }^{19}$ and VEGF is one of the most potent stimulators of angiogenesis. ${ }^{20}$

Limited studies indicate that $\mathrm{PGE}_{2}$ is critical for wound healing $^{21}$ and that its level is positively correlated with wound healing rate. ${ }^{22}$ Moreover, $\mathrm{PGE}_{2}$ concentration is reduced in cutaneous wounds of diabetic mice. ${ }^{22}$ Paradoxically, cyclooxygenases (COX1 and COX2) and all $\mathrm{PGE}_{2}$ terminal synthases are unchanged or increased in diabetic skin. ${ }^{22}$ This suggests that the decrease in $\mathrm{PGE}_{2}$ abundance is not linked to a defect in production, but instead could be due to increased catabolism of $\mathrm{PGE}_{2}$.

Supported by grants from the American Heart Association (0735066N to Y.C.) and the American Diabetes Association (1-11-JF-06 to Y.C.).

Accepted for publication March 15, 2012.

A guest editor acted as editor-in-chief for this manuscript. No person currently or formerly at Albert Einstein College of Medicine was involved in the peer review process or final disposition for this article.

Supplemental material for this article can be found at http://ajp. amjpathol.org or at http://dx.doi.org/10.1016/j.ajpath.2012.03.012.

Address reprint requests to Yuling Chi, Ph.D., Department of Medicine, Albert Einstein College of Medicine, 1300 Morris Park Ave., Ullmann Bldg. Room 617, Bronx, NY 10461. E-mail: yuling.chi@einstein.yu.edu. 
Catabolism and degradation of $\mathrm{PGE}_{2}$ are mediated by inward transport by the $P G$ transporter (PGT) that delivers $\mathrm{PGE}_{2}$ to intracellular catabolic enzymes. ${ }^{23} \mathrm{Ge}$ netic deletion and chemical inhibition of PGT prevent the degradation of $\mathrm{PGI}_{2}$ and $\mathrm{PGE}_{2}$, and elevate the blood levels of these prostanoids, ${ }^{24,25}$ indicating that PGT regulates systemic $\mathrm{PGE}_{2}$ catabolism. Here, we report the important finding that PGT is up-regulated by hyperglycemia, resulting in weakened $\mathrm{PGE}_{2}$ signaling both in cultured cells and in diabetic wounds. Weakened $\mathrm{PGE}_{2}$ signaling causes attenuated angiogenic responses, which can be corrected by pharmacological inhibition of PGT. These data indicate that up-regulated PGT signaling in wounds is a fundamental contributor to weakened wound healing responses in diabetes and identifies PGT as a therapeutic target for DFU treatment.

\section{Materials and Methods}

\section{Cell Culture}

Human dermal microvascular endothelial cells (HDMECs), human epidermal keratinocytes (HEKs) (human dermal epithelial cells), and human dermal fibroblasts were purchased from ScienCell Research Laboratories (Carlsbad, CA). HDMECs were cultured in endothelial cell medium (ECM) containing 5\% fetal bovine serum, $1 \%$ endothelial cell growth supplement (ScienCell Research Laboratories), $1 \%$ penicillin-streptomycin, and $5 \mathrm{mmol} / \mathrm{L}$ glucose. HEKs were cultured in keratinocyte medium containing $1 \%$ keratinocyte growth supplement (ScienCell Research Laboratories), $1 \%$ penicillin-streptomycin, and $5 \mathrm{mmol} / \mathrm{L}$ glucose. Human dermal fibroblasts were cultured in Dulbecco's modified Eagle's medium containing 10\% fetal bovine serum, $1 \%$ penicillin-streptomycin, and $5 \mathrm{mmol} / \mathrm{L}$ glucose. siRNAs (PGT and GFP) were purchased from Qiagen (Valencia, CA).

\section{PGT Activity Assay}

PGT activity was measured by $\left[{ }^{3} \mathrm{H}\right] \mathrm{PGE}_{2}$ uptake in HDMECs in medium containing 5 or $25 \mathrm{mmol} / \mathrm{L}$ glucose, in the presence or absence of $5 \mu \mathrm{mol} / \mathrm{L}$ T26A, using a method described previously. ${ }^{26}$

\section{$P G E_{2}$ Measurements in Cell Culture}

Four hundred thousand HDMECs were seeded onto $10-\mathrm{cm}$ plates and incubated in ECM containing 5 or 25 $\mathrm{mmol} / \mathrm{L}$ glucose at $37^{\circ} \mathrm{C}$ for 3 days, then were treated with $10 \mu \mathrm{mol} / \mathrm{L}$ bradykinin in the presence or absence of 5 $\mu \mathrm{mol} / \mathrm{L}$ T26A for 3 hours. Bradykinin was used to stimulate endogenous $\mathrm{PGE}_{2}$ synthesis, to better enable $\mathrm{PGE}_{2}$ detection. The cell medium was collected and $\mathrm{PGE}_{2}$ was assayed with an enzyme immunoassay kit (Cayman Chemical, Ann Arbor, MI). Cellular protein was determined with a BCA protein assay kit (Thermo Scientific, Pittsburgh, PA), and the $\mathrm{PGE}_{2}$ level was normalized to total cellular protein.

\section{PGT siRNA Effect on Endogenous $\mathrm{PGE}_{2}$}

HDMECs were seeded onto six-well plates. Twenty-four hours later, when confluency reached $40 \%$ to $60 \%$, cells were transfected with four sets of siRNAs targeting PGT at various concentrations and with GFP siRNA, using RNAi Max transfection reagent (Invitrogen-Life Technologies, Carlsbad, CA). GFP siRNA was used as a positive/ negative control to determine transfection efficiency and the effect of silencing, without affecting the PGT gene. Maximal silencing of PGT mRNA (80\%) was achieved by transfecting PGT siRNA set 1 at a concentration of $10 \mathrm{nmol} / \mathrm{L}$. To determine the effect of PGT siRNA on endogenous $\mathrm{PGE}_{2}$ levels, HDMECs were seeded onto six-well plates and incubated in medium containing 5 or $25 \mathrm{mmol} / \mathrm{L}$ glucose. Twenty-four hours later, cells were transfected with either GFP or PGT siRNA. Two days after transfection, cells were treated with $10 \mu \mathrm{mol} / \mathrm{L}$ bradykinin for 3 hours. The cell medium was collected and $\mathrm{PGE}_{2}$ was assayed, using an enzyme immunoassay kit from Cayman Chemical. Cellular protein was determined using a BCA protein assay kit (Thermo Scientific), and the PGE 2 level was normalized to total cellular protein.

\section{Cellular Wound Migration}

Fifty thousand HDMECs or HEKs seeded onto six-well plates (with premarked center) were grown in ECM or keratinocyte medium containing 5 or $25 \mathrm{mmol} / \mathrm{L}$ glucose at $37^{\circ} \mathrm{C}$, reaching $100 \%$ confluency in 3 to 4 days. A gap in cells was created with a pipette tip of diameter of 1 $\mathrm{mm}$. Cells were washed with PBS and incubated in ECM or keratinocyte medium containing 5 or $25 \mathrm{mmol} / \mathrm{L}$ glucose in the presence or absence of $100 \mathrm{nmol} / \mathrm{L} \mathrm{PGE}$ or $5 \mu \mathrm{mol} / \mathrm{L}$ T26A. Phase-contrast photomicrographs were taken immediately and at 12 hours using a microscope ( $4 \times$ objective). The open area (ie, not covered by cells) in the center of the well at 0 and 12 hours was determined using ImageJ software version 1.45s $(\mathrm{NIH}$, Bethesda, $\mathrm{MD})$. The closed area was calculated by subtracting the open area at 12 hours from the open area at 0 hours. The percentage gap closure was calculated by dividing the closed area by the open area at 0 hours and multiplying by 100 . After photomicrographs were obtained, cells were collected in TRIzol reagent (Invitrogen-Life Technologies, Carlsbad, CA) for RNA measurements.

\section{Cell Migration Transwell Assay}

The cell migration Transwell assay was performed as described previously, ${ }^{27}$ with slight modification. Fifty thousand HDMECs pretreated with 5 or $25 \mathrm{mmol} / \mathrm{L}$ glucose for 3 days were seeded in $300 \mu \mathrm{L}$ serum-free ECM containing 5 or $25 \mathrm{mmol} / \mathrm{L}$ glucose on the top side of filters that were subsequently placed in 24-well plates with ECM (with serum) containing 5 or $25 \mathrm{mmol} / \mathrm{L}$ glucose in the presence or absence of $100 \mathrm{nmol} / \mathrm{L} \mathrm{PGE}$ or 5 $\mu \mathrm{mol} / \mathrm{L}$ T26A. After incubation at $37^{\circ} \mathrm{C}$ for 12 hours, cells were fixed with $4 \%$ paraformaldehyde at $25^{\circ} \mathrm{C}$ for 1 hour, and stained with $0.1 \%$ crystal violet for 1 hour. Cells on 
the bottom of the filter (ie, migrated cells) were counted under a microscope with a $10 \times$ objective. $^{27}$

\section{Tube Formation}

The tube formation assay was adapted from methods described previously. ${ }^{28}$ Briefly, Cytodex-3 microcarrier beads (Sigma-Aldrich, St. Louis, MO, and GE Healthcare, Piscataway, $\mathrm{NJ}$ ) coated with HDMECs (pretreated with 5 or $25 \mathrm{mmol} / \mathrm{L}$ glucose for 2 days) at $37^{\circ} \mathrm{C}$ for 16 hours were suspended in fibrinogen solution ( $2 \mathrm{mg} / \mathrm{mL}$ in PBS) containing 5 or $25 \mathrm{mmol} / \mathrm{L}$ glucose in the presence or absence of $100 \mathrm{nmol} / \mathrm{L} \mathrm{PGE}_{2}$ or $5 \mu \mathrm{mol} / \mathrm{L} \mathrm{T26A}$ and were added to 24-well plates $(0.5 \mathrm{~mL}$ suspension per well) in the presence of $6.25 \mu \mathrm{L}$ thrombin $(0.625 \mathrm{U} / \mathrm{mL})$. After the bead suspension had solidified, $0.6 \mathrm{~mL}$ ECM containing 5 or $25 \mathrm{mmol} / \mathrm{L}$ glucose in the presence or absence of $100 \mathrm{nmol} / \mathrm{L} \mathrm{PGE} \mathrm{PG}_{2}$ or $5 \mu \mathrm{mol} / \mathrm{L}$ T26A and human dermal fibroblasts was added to each well. The bead and human dermal fibroblast mixtures were incubated at $37^{\circ} \mathrm{C}$ for 72 hours. Photographs were taken every 24 hours. The number of tubes per bead was determined and the length of tubes was measured using the averaged bead diameter as reference.

\section{Protein Extraction}

Tissues or cells were washed with ice-cold PBS and lysed with protein lysis buffer $(20 \mathrm{mmol} / \mathrm{L}$ Tris $\mathrm{pH} 7.4,150$ $\mathrm{mmol} / \mathrm{L} \mathrm{NaCl}, 1 \mathrm{mmol} / \mathrm{L}$ EDTA, $1 \mathrm{mmol} / \mathrm{L} \mathrm{NaF}, 1 \mathrm{mmol} / \mathrm{L}$ $\mathrm{Na}_{3} \mathrm{VO}_{4}, 1 \% \mathrm{NP}-40$, and protease inhibitor cocktail). The cell lysate was kept on ice for 30 minutes with shaking or light vortex mixing intermittently. The lysate was centrifuged at $4^{\circ} \mathrm{C}$ at $13,000 \times g$ for 15 minutes. The supernatant was transferred into a clean Eppendorf tube. Protein concentration was determined using a BCA protein assay kit (Thermo Scientific). The supernatant was mixed with loading buffer and boiled for 5 minutes. The protein samples were aliquoted and stored at $-80^{\circ} \mathrm{C}$.

\section{Western Blot}

Protein samples were fractioned on 10\% SDS-PAGE and were transferred to polyvinylidene difluoride membrane. The membrane was incubated in 5\% non-fat milk at room temperature for 1 hour and subsequently incubated with anti-VEGF polyclonal antibody (Santa Cruz Biotechnology, Santa Cruz, CA) or anti-PGT polyclonal antibody (Cayman Chemical) diluted in $5 \%$ milk ( 0.5 to $1 \mu \mathrm{g} / \mathrm{mL}$ ) at $4^{\circ} \mathrm{C}$ overnight. Goat anti-rabbit IgG horseradish peroxidase-linked antibody in wash buffer with $0.5 \%$ milk (1:2000 dilution) was added to the membrane and incubated at room temperature for 1 hour. Secondary antibody was detected using SuperSignal West Pico chemiluminescent substrate (Thermo Scientific) followed by autoradiography. The protein bands were quantified using ImageJ software.

\section{mRNA Measurement by Real-Time qRT-PCR}

Total RNA was extracted with TRIzol, and $1 \mu \mathrm{g}$ of total RNA was used to synthesize cDNA with SuperScript III Reverse Transcriptase and Oligo(dT) (Invitrogen-Life Technologies). Real-time PCR with SYBR Green master mix was performed using a 7900HT PCR system (Applied Biosystems-Life Technologies, Foster City, CA) with the following primers: VEGF (human), 5'-AGCTGCGCTGATAGACATCC-3' (forward) and 5'-GTCTGAACGTCTCAAAGGGC-3' (reverse); VEGF (mouse), 5'-AATGCTTTCTCCGCTCTGAA-3' (forward) and 5'-GCTTCCTACAGCACAGCAGA-3' (reverse); PGT (human), 5'-TGTACAGGAGTTGGCAGAGC-3' (forward) and 5'-AGCGACACCTCTACTAGCCG-3' (reverse); PGT (mouse), 5'-TCGATAGTGGTGAGGCTGCT-3' (forward) and 5'-CGCTCGGTCTTCAACAACAT-3' (reverse); GAPDH (human), 5'-AATGAAGGGGTCATTGATGG-3' (forward) and 5'-AAGGTGAAGGTCGGAGTCAA-3' (reverse); and GAPDH (mouse), 5'-TTGATGGCAACAATCTCCAC-3' (forward) and 5'-CGTCCCGTAGACAAAATGGT-3' (reverse). The level of mRNA was calculated versus GAPDH transcript and was expressed as fold over control.

\section{Animals}

Male BKS.Cg-Dock $7^{m}+/+L e p r^{\mathrm{db}} / \mathrm{J}$ mice and their matched control, C57BLKS, all 10 weeks of age, were purchased from the Jackson Laboratory (Bar Harbor, ME). To generate diabetic mice, wild-type (WT) C57BL6/J mice, 5 to 6 weeks of age, were purchased from the Jackson Laboratory and injected with streptozotocin (STZ) (50 mg/kg body weight) or saline solution at one dose per day for 5 days consecutively. Mice injected with saline were used as controls.

\section{Wound Creation and Care}

All procedures were approved by the Institutional Care and Use Committee at Albert Einstein College of Medicine (AECOM). Two 5-mm full-thickness cutaneous wounds were created on opposite sides of the dorsum in the mice. ${ }^{29}$ One 10-mm cutaneous wound was created on the dorsum of each mouse for blood flow measurement. Either 15 or 50 $\mu \mathrm{L}$ of vehicle [2\% Kolliphor EL (polyethoxylated castor oil; catalog no. C5135; Sigma-Aldrich) + 2\% DMSO in water)] or T26A was applied to wounds immediately after wounding and every other day thereafter. Wounds were covered with fresh Tegaderm dressing (3M, Maplewood, MN) after each application.

\section{Wound Closure Measurements}

Images of wounds, with a ruler within the visual field for scale, were obtained using a digital camera. Wound sizes were analyzed using ImageJ software. The open wound was defined as the unepithelialized area, and the number of pixels were counted for quantification. Wound closure was calculated as a percentage versus the initial wound area. 


\section{Histological Examination and Evaluation of Wounds}

At various time points, wounded mice were sacrificed for histological examination. Bromodeoxyuridine (BrdU) was intraperitoneally injected into mice (100 $\mu \mathrm{g} / \mathrm{g}$ body weight) 3 hours before sacrifice. Unwounded skin and wounded skin tissues were excised and carefully placed and stapled onto cardboard to flatten the sample. Tissues were fixed with $4 \%$ paraformaldehyde for 18 to 20 hours, trimmed at the center of the wound, and processed with paraffin. The paraffin-embedded sections (5 $\mu \mathrm{m}$ thick) were stained with $\mathrm{H} \& \mathrm{E}$, and additional sections were stained immunohistochemically for BrdU (mouse monoclonal antibody; Roche Applied Science, Indianapolis, IN), CD34 (mouse monoclonal antibody; Cedarlane Laboratories, Burlington, NC), and PGT (rabbit polyclonal antibody; Cayman Chemical). Samples for immunohistochemistry were dewaxed in xylene and rehydrated through successive grades of alcohol to water. For antigen retrieval, slides were placed in $6 \mathrm{~mol} / \mathrm{L}$ sodium citrate buffer $\mathrm{pH} 6.2$ and maintained at $95^{\circ} \mathrm{C}$ for 20 minutes, followed by cooling to room temperature. Endogenous peroxidase activity was blocked using peroxidase blocking solution (Dako, Carpinteria, CA). The slides for BrdU staining were additionally exposed to $3 \mathrm{~mol} / \mathrm{L} \mathrm{HCl}$ for 30 minutes at room temperature and washed in TBS.

Samples were incubated in blocking buffer [5\% donkey serum (Jackson ImmunoResearch Laboratories, West Grove, PA) and 2\% BSA (Sigma-Aldrich)]. Samples were then exposed to primary antibodies: CD34 and BrdU 1:400 for 1 hour at room temperature and PGT $1: 250$ at $4^{\circ} \mathrm{C}$ overnight. Samples were washed and then exposed to either mouse or rabbit polymer (InvitrogenLife Technologies), followed by exposure to 3,3'-diaminobenzidine (DAB) and water wash. Samples were evaluated by a Board-certified veterinary pathologist (R.S.S.), and photomicrographs were acquired under a microscope with a $10 \times$ or $20 \times$ objective. For quantification of BrdU positivity, the number of positive cells per highpower field (HPF) was counted in a masked fashion under a microscope. Because CD34 is not an entirely specific marker for endothelial cells, only those cells that were both DAB positive and morphologically consistent with endothelial cells were included in the evaluation.

\section{Blood Flow}

A single cutaneous wound $10 \mathrm{~mm}$ in diameter was created on the dorsum of mice, using the procedure described above. Blood flow in the wound was measured using a PeriScan PIM 3 laser Doppler blood perfusion imaging system (Perimed, Järfälla, Sweden) immediately after wounding and every other day, before application of $50 \mu \mathrm{L}$ of vehicle or T26A. During measurements, mice were placed on a $37^{\circ} \mathrm{C}$ heating pad and anesthetized with $2.5 \%$ isoflurane. Blood flow in adjacent unwounded skin was measured and used as a reference for relative blood flow calculation.

\section{Wound Collection for Extractions of Protein and Total RNA and Measurement of PGE ${ }_{2}$ in Skin Tissues}

At various time points, wound tissues were excised at a diameter of $7 \mathrm{~mm}$, circumscribing the original 5- $\mathrm{mm}$ wound diameter. Three quarters of the tissue was used for protein extraction; the remainder was used for extraction of total RNA. All harvested tissues were immediately frozen in liquid nitrogen. For $\mathrm{PGE}_{2}$ measurements, a separate set of wound tissues were collected, and whole wound was used for $\mathrm{PG}$ extraction and $\mathrm{PGE}_{2}$ assay using an enzyme immunoassaykit (Cayman Chemical).

\section{Measurements of VEGF Protein in Skin Tissues}

Protein was extracted from frozen skin tissues. VEGF in the sample was measured using a Quantikine ELISA kit (R\&D Systems, Minneapolis, MN) and was normalized to total protein.

\section{Statistical Analysis}

Group measurements are expressed as means \pm SD or as means \pm SEM. Comparisons of two groups were performed with $t$-tests. All statistical tests were two-sided, and $P<0.05$ was considered significant.

\section{Results}

\section{Hyperglycemia Augments PGT Expression and Activity in HDMECs}

In cultured cells, PGT expression reaches steady levels between day 3 and day 4 . Hyperglycemia causes significant inhibitory effects on endothelial cell functions on day $4{ }^{30}$ To examine the effect of glucose on PGT expression in HDMECs, we exposed cells to hyperglycemia for 4 days. This caused a two- to threefold increase in both PGT protein and mRNA levels, compared with control (Figure 1, A and B). To determine whether PGT activity was also increased, we measured $\left[{ }^{3} \mathrm{H}\right] \mathrm{PGE}_{2}$ uptake by HDMECs in euglycemia or hyperglycemia. As expected, hyperglycemia increased PGT activity by twofold, compared with control (Figure $1 \mathrm{C}$ ). These results indicate that hyperglycemia induces PGT expression and activity in HDMEC cells. This is, to our knowledge, the first evidence that PGT expression and activity are sensitive to glucose concentration in dermal endothelial cells.

To investigate whether hyperglycemia or modulation of PGT activity or expression can affect extracellular $\mathrm{PGE}_{2}$ levels, we measured $\mathrm{PGE}_{2}$ secreted into the medium by HDMECs in euglycemia or hyperglycemia in the presence or absence of a potent PGT inhibitor, T26A. We recently reported that $\mathrm{T} 26 \mathrm{~A}$ is a highly selective inhibitor of PGT. ${ }^{25}$ This compound blocks PGE 2 catabolism and degradation without affecting $\mathrm{PGE}_{2}$ synthesis, owing to its ability to prevent $\mathrm{PGE}_{2}$ internalization in cells. ${ }^{25}$ Exposure to hyperglycemia for 4 days decreased extracellular $\mathrm{PGE}_{2}$ to $50 \%$ of control (Figure 1D). Inhibition of PGT by 

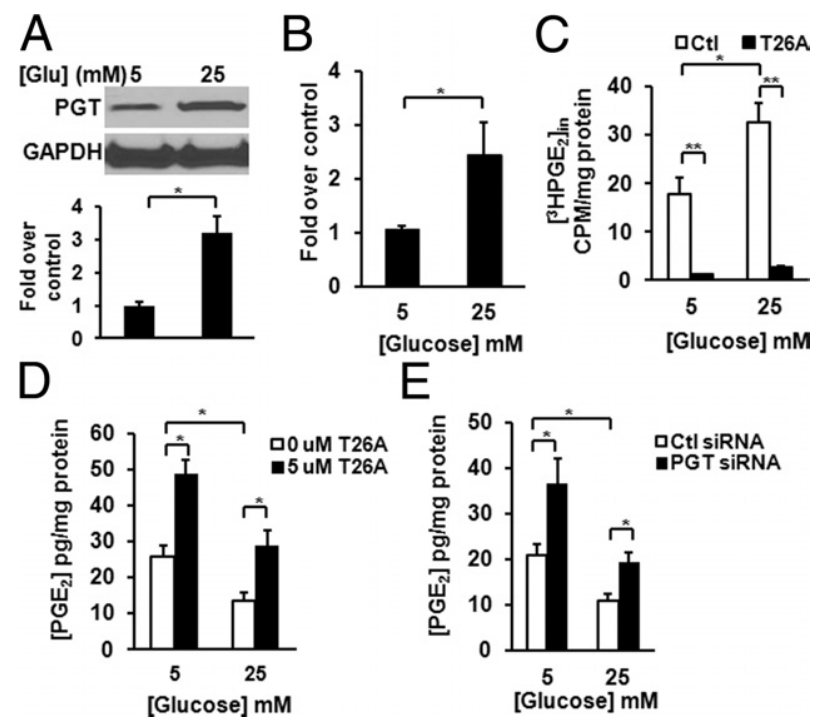

$E$

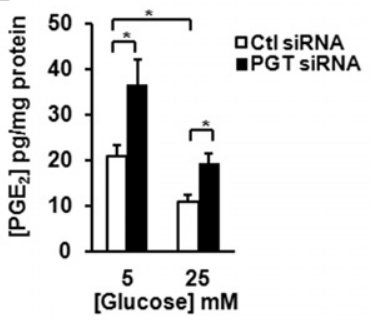

Figure 1. Hyperglycemia augments PGT expression and activity in HDMECs. A and B: Expression of PGT protein (A) and PGT mRNA (B) in HDEMCs incubated in medium containing 5 or $25 \mathrm{mmol} / \mathrm{L}$ glucose for 4 days. C: $\left[{ }^{3} \mathrm{H}\right] \mathrm{PGE}_{2}$ uptake by HDMECs incubated in medium containing 5 or 25 $\mathrm{mmol} / \mathrm{L}$ glucose for 4 days. D: Endogenous $\mathrm{PGE}_{2}$ secreted by HDMECs incubated in medium containing 5 or $25 \mathrm{mmol} / \mathrm{L}$ glucose for 4 days and treated with $10 \mu \mathrm{mol} / \mathrm{L}$ bradykinin and 0 or $5 \mu \mathrm{mol} / \mathrm{L}$ T26A for 3 hours. E: Endogenous $\mathrm{PGE}_{2}$ secreted by HDMECs transfected with GFP siRNA as a control or PGT siRNA and exposed to 5 or $25 \mathrm{mmol} / \mathrm{L}$ glucose for 4 days and treated with $10 \mu \mathrm{mol} / \mathrm{L}$ bradykinin for 3 hours. These experiments were conducted for three rounds, each round in duplicate for each condition. Data are expressed as means $\pm \mathrm{SD}(n=6) .{ }^{*} P<0.05 ;{ }^{* *} P<0.01$. CPM, counts per minute; Ctl, control.

T26A for 3 hours doubled extracellular $\mathrm{PGE}_{2}$ in hyperglycemia and also increased $\mathrm{PGE}_{2}$ levels in controls. To confirm that the increased $\mathrm{PGE}_{2}$ by T26A was a direct result of $P G T$ inhibition, we transfected HDMECs with PGT siRNA and measured $P G E_{2}$ release. Suppression of PGT increased extracellular $\mathrm{PGE}_{2}$ to $180 \%$ of control in euglycemia and reversed the decrease in $\mathrm{PGE}_{2}$ levels caused by hyperglycemia (Figure 1E). Thus, data obtained by both chemical and genetic approaches are consistent with a model in which increased PGT expression and activity induced by hyperglycemia cause reduced $\mathrm{PGE}_{2}$ concentrations.

\section{Up-Regulated PGT Causes Hyperglycemia- Induced Defects in HDMEC Migration and Wound Closure}

To investigate effects of hyperglycemia induction of PGT on wound closure in vitro, we created a one-dimensional gap in confluent HDMEC monolayers; we then exposed these HDMECs to hyperglycemic or euglycemic conditions and measured wound closure after 12 hours. Without added $\mathrm{PGE}_{2}$ or T26A, 30\% of the gap closed in euglycemia, whereas only $13 \%$ of the gap closed in hyperglycemia (Figure 2A; see also Supplemental Figure S1A at http://ajp.amjpathol.org). Reports that $\mathrm{PGE}_{2}$ stimulates cellular migration ${ }^{27,31}$ led us to test whether the defect in wound closure could be due to a deficit in $\mathrm{PGE}_{2}$ signaling secondary to PGT up-regulation. We applied $100 \mathrm{nmol} / \mathrm{L} \mathrm{PGE}_{2}$ or $5 \mu \mathrm{mol} / \mathrm{L}$ T26A to cells and observed that in euglycemia $100 \mathrm{nmol} / \mathrm{L} \mathrm{PGE}_{2}$ caused $55 \%$ gap closure. The effect of $5 \mu \mathrm{mol} / \mathrm{L}$ T26A was even greater than that of $\mathrm{PGE}_{2}$ (Figure 2). More importantly, T26A reversed the effects of hyperglycemia on HDMEC migration, similar to what occurs with added $\mathrm{PGE}_{2}$ (Figure 2A; see also Supplemental Figure S1A at http://ajp.amjpathol. org). These data are consistent with the idea that PGT regulates cell migration in both euglycemia and hyperglycemia by modulating $\mathrm{PGE}_{2}$ signaling.

We confirmed the influence of hyperglycemia and PGT on cell migration by another assay, the Transwell assay. ${ }^{27,31}$ Hyperglycemia impaired HDMEC mobility, reducing the number of migrated cells to $50 \%$ of that observed in euglycemia (Figure 2B; see also Supplemental Figure S1B at http://ajp.amjpathol.org). Treatment of hyperglycemic cultures with $\mathrm{PGE}_{2}$ or T26A restored HDMEC mobility to nearly control levels. These data are consistent with the idea that hyperglycemia up-regulates PGT expression and activity, which in turn weakens $\mathrm{PGE}_{2}$ signaling and cell migration. The results obtained by the two migration assays show that hyperglycemia impairs cell migration. The impairment can be corrected by pharmacological inhibition of PGT, suggesting that PGT upregulation is fundamental to migration defects caused by hyperglycemia.

\section{Up-Regulated PGT Causes Hyperglycemia- Impaired Capillary Formation in HDMECs}

To further investigate the role of hyperglycemia and PGT in angiogenesis, we performed the fibrin bead assay, ${ }^{28}$ in which endothelial cells are coated onto beads and the formation of microtube structures is evaluated. The number of sprouts per bead and the length of sprouts were used as measures of angiogenic behavior. ${ }^{28}$ After 24 hours, cells formed sprouts of discernible and quantifi-

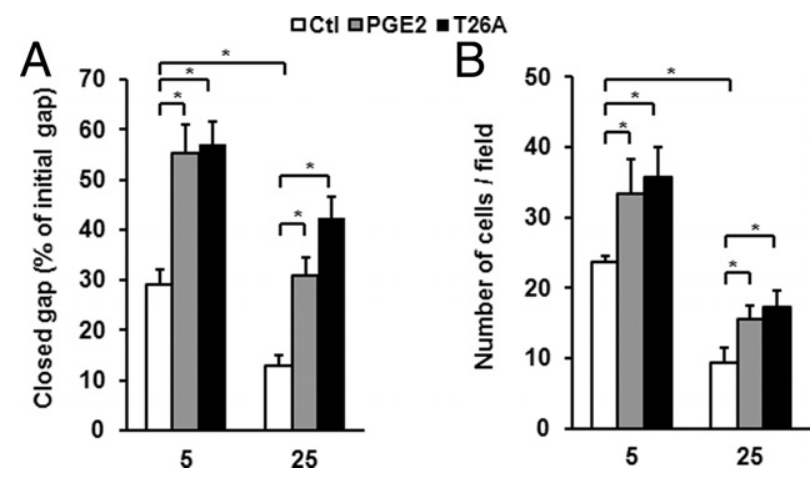

Figure 2. Up-regulated PGT causes hyperglycemia-induced defects in HDMEC wound migration. A: Analysis of HDMEC gap closure as percentage of closed gap relative to the initial gap. HDMECs were incubated in medium containing 5 or $25 \mathrm{mmol} / \mathrm{L}$ glucose for 4 days on six-well plates to reach $100 \%$ confluency. Gaps were created in the center of each well; thereafter, cells were incubated in medium containing 5 or $25 \mathrm{mmol} / \mathrm{L}$ glucose in the presence or absence of $100 \mathrm{nmol} / \mathrm{L} \mathrm{PGE} 2$ or $5 \mu \mathrm{mol} / \mathrm{L}$ T26A for 12 hours. B: Analysis of Transwell assay of HDMECs migrated through filters. HDMECs were preconditioned in medium containing 5 or $25 \mathrm{mmol} / \mathrm{L}$ glucose for 4 days, then seeded onto Matrigel-coated filters, which were then inserted into medium containing 5 or $25 \mathrm{mmol} / \mathrm{L}$ glucose in the presence or absence of $100 \mathrm{nmol} / \mathrm{L} \mathrm{PGE} 2$ or $5 \mu \mathrm{mol} / \mathrm{L}$ T26A and incubated for 12 hours. These experiments were conducted for three rounds, each round in duplicate for each condition. Data are expressed as means $\pm \mathrm{SD}(n=6) .{ }^{*} P<0.05$ 
A

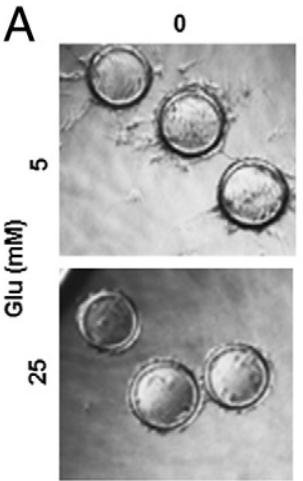

$100 \mathrm{nM} \mathrm{PGE}_{2}$

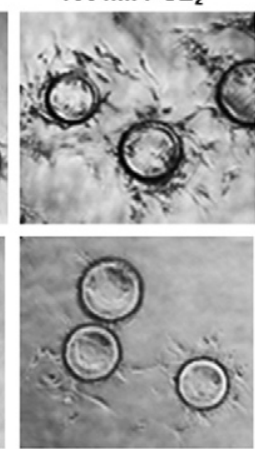

$5 \mu \mathrm{M}$ T26A

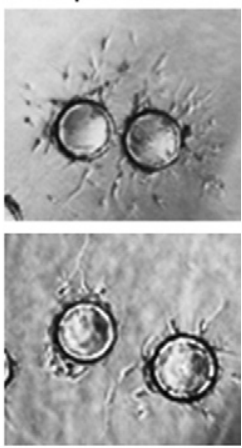

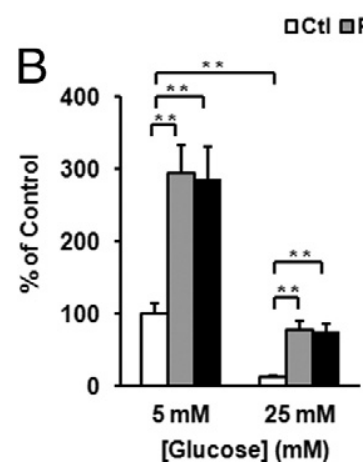

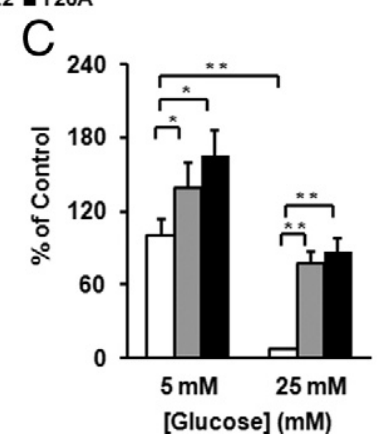

Figure 3. Up-regulated PGT causes hyperglycemia-impaired capillary formation in HDMECs. A: Representative photomicrographs of HDMEC capillary formation. HDMEC-coated beads were suspended in fibrinogen solution containing $5 \mathrm{mmol} / \mathrm{L}$ or $25 \mathrm{mmol} / \mathrm{L}$ glucose $\pm 100 \mathrm{nmol} / \mathrm{L} P_{2} E_{2}$ or $5 \mu \mathrm{mol} / \mathrm{L}$ T26A, solidified in 24-well plates in the presence of thrombin and covered with serum-free ECM containing $5 \mathrm{mmol} / \mathrm{L}$ or $25 \mathrm{mmol} / \mathrm{L}$ glucose \pm 100 $\mathrm{nmol} / \mathrm{L}$ PGE 2 or $5 \mu \mathrm{mol} / \mathrm{L}$ T26A and human dermal fibroblasts, and incubated for 24 hours. Original magnification, $\times 10$. B: The number of HDMEC tubes was counted in five randomly chosen fields. The average number of tubes per bead was calculated by dividing the total number of tubes by the total number of beads. $\mathbf{C}$ : For measurement of tube length, the images shown in A were digitally enlarged using Adobe Photoshop software version CS3 extended (Adobe Systems, Inc., San Jose, CA); tube length was measured, using the averaged diameter of beads as reference. For each condition, 25 beads were randomly chosen. These experiments were conducted for three rounds, each round in duplicate for each condition. Data are expressed as means $\pm \mathrm{SD}(n=6) .{ }^{*} P<0.05 ;{ }^{* *} P<0.01$.

able length in euglycemia (Figure 3, A-C). Both $\mathrm{PGE}_{2}$ and T26A tripled the number of vessels (Figure 3, A and B) and increased the length of tubes to $130 \%$ to $170 \%$ of control (Figure 3, A and C). In contrast, hyperglycemia ablated tube formation. Both T26A and $\mathrm{PGE}_{2}$ treatments in hyperglycemia provided correction, leading to increases in sprout numbers to $80 \%$ of control and increases in tube length to $90 \%$ of control. These data imply that overactivation of PGT in hyperglycemia impairs HDMEC angiogenic functions, which can be restored by pharmacological PGT inhibition.

\section{PGT Expression Is Induced by Wounding and Diabetes, and Inhibition of PGT Elevates PGE 2 in Wounds}

To determine whether increased PGT expression with hyperglycemia observed in cell culture also occurs in vivo, we stained for PGT protein in unwounded skin of C57BLKS and BKS.Cg-Dock7 ${ }^{\mathrm{m}}+/+$ Lepr $^{\mathrm{db}} / \mathrm{J}(\mathrm{db} / \mathrm{db})$ mice; the latter mouse strain is hyperglycemic and is widely used for diabetic wound healing studies. ${ }^{32-36}$ PGT protein expression is minimal in WT mice, whereas it is clearly apparent in $d b / d b$ mice (Figure $4 A$ ). At the mRNA level, PGT transcript is 4.5 -fold higher in $d b / d b$ mice than
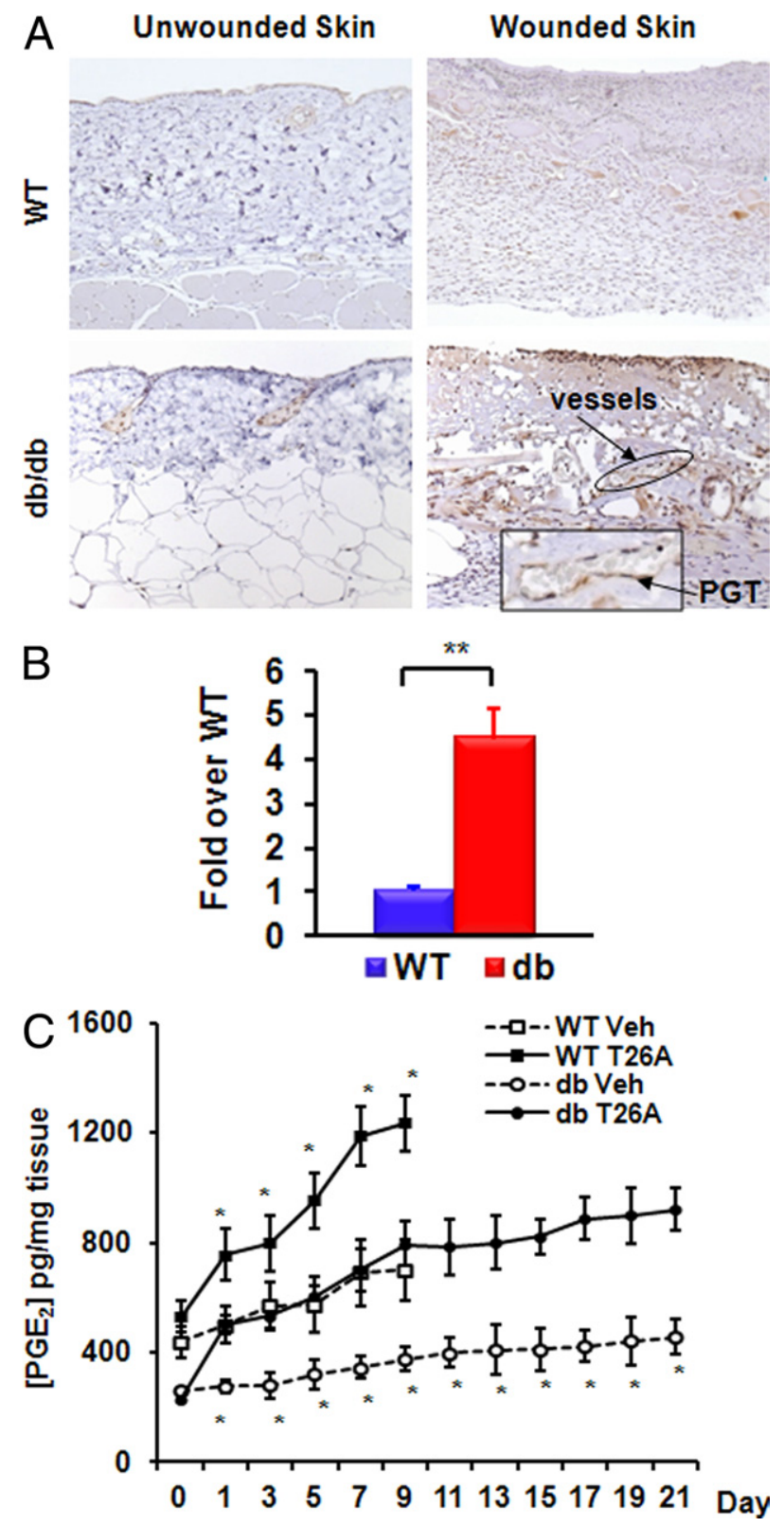

Figure 4. PGT expression is induced by wounding and diabetes, and inhibition of PGT elevates $\mathrm{PGE}_{2}$ in wounds. A: Representative photomicrographs of PGT staining of unwounded and wounded skin of WT C57BLKS (day 5 after wounding) and BKS.Cg-Dock $7^{m}+/+L e p r^{d b} / \mathrm{J} d b / d b$ mice (day 7 after wounding). Original magnification, $\times 20$. B: For measurement of PGT mRNA in unwounded skin of WT and $d b / d b$ mice, skin tissues were collected from five mice of each strain. mRNA was measured three times for each sample. C: For analysis of $\mathrm{PGE}_{2}$ levels in mouse wound tissues as a function of time, two 5-mm cutaneous wounds were created on opposite sides of the dorsum; $15 \mu \mathrm{L}$ of vehicle ( $2 \%$ Kolliphor EL $+2 \%$ DMSO in water) was applied to one wound and $2 \mathrm{mmol} / \mathrm{L}$ T26A was applied to the other immediately after wounding and every other day thereafter throughout the entire course of wound healing. At various time points ( 0 to 21 days), wound tissues were collected for PG extraction and $\mathrm{PGE}_{2}$ assay using an enzyme immunoassay kit from Cayman Chemical. PGE was measured three times for each wound tissue. Data are expressed as means $\pm \operatorname{SEM}[n=5(\mathbf{B}) ; n=4$ mice per time point $(\mathbf{C})]\left[.{ }^{*} P<0.05 ;{ }^{* *} P<0.01\right.$. 

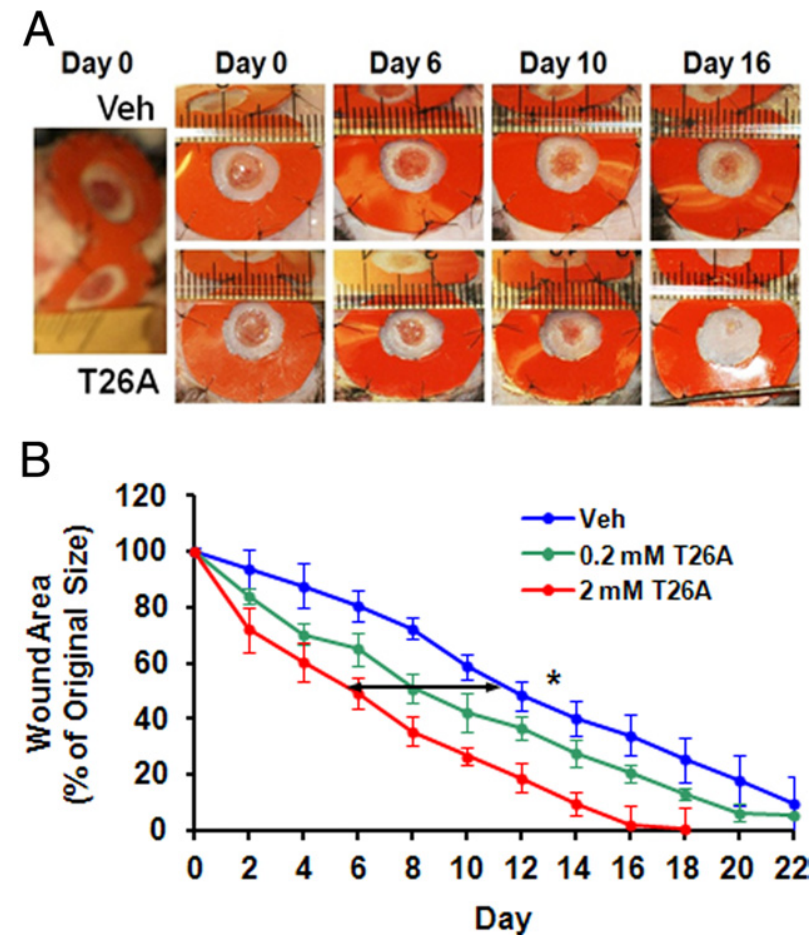

Figure 5. PGT modulates wound healing rates in diabetic mice. A: Photomicrographs of representative wounds of BKS.Cg-Dock $7^{m}+/+L e p r^{d b} / \mathrm{J}$ $d b / d b$ mice at various time points after wounding (day 0 to 16 ). Two $5-\mathrm{mm}$ cutaneous wounds were created on opposite sides of the dorsum of five mice; $15 \mu \mathrm{L}$ of vehicle ( $2 \%$ Kolliphor EL $+2 \%$ DMSO in water) was applied to one wound and T26A was applied to the other immediately after wounding and every other day thereafter. B: Wound area as a function of time analyzed using ImageJ software. Scale $(\mathbf{A})$ is in millimeters.

in WT mice (Figure 4B). This recapitulates our observations in cell culture that hyperglycemia induces PGT expression in vitro (Figure 1, A and B). The in vitro and in vivo data together uncover a mechanism that could help to explain wound healing defects in diabetes.

To further investigate factors that affect PGT expression, we determined PGT levels in wounds. Unexpectedly, wounding induced a profound expression of PGT in both WT and $d b / d b$ mouse wounds, although to a much greater extent in $d b / d b$ animals (Figure 4A). PGT expression reached a peak level on day 5 in WT mouse wounds and on day 7 in $d b / d b$ mouse wounds. PGT was expressed in macrophages, endothelial cells around vessels, and fibroblasts. These findings indicate that in vivo PGT expression is sensitive to trauma and is more prominently stimulated in diabetic animals. This effect, combined with our in vitro data linking hyperactivation of PGT expression and activity to defects in cell behaviors fundamental to wound healing, led us to propose that PGT could play a contributing role in impaired wound healing in diabetic animals.

The predicted downstream effect of PGT overexpression is diminished $\mathrm{PGE}_{2}$ level. $\mathrm{PGE}_{2}$ levels during the course of wound healing in both WT and $d b / d b$ mice are shown in Figure 4C. In vehicle-treated wounds of both strains, the $\mathrm{PGE}_{2}$ level dropped to its lowest values immediately after wounding. $\mathrm{PGE}_{2}$ levels gradually recovered, ultimately reaching a stable level, similar to that of adjacent intact WT skin (858 $\pm 62 \mathrm{pg} / \mathrm{mg}$ tissue) or $\mathrm{db} / \mathrm{db}$ skin (423 $\pm 35 \mathrm{pg} / \mathrm{mg}$ tissue). In diabetic wounds, $\mathrm{PGE}_{2}$ level is consistently $<50 \%$ of WT wounds at all times (Figure 4C). T26A application caused increased $\mathrm{PGE}_{2}$, compared with the respective controls. Application of T26A throughout the entire course of wound healing significantly increased $\mathrm{PGE}_{2}$ levels in WT wounds; more importantly, it corrected $\mathrm{PGE}_{2}$ deficit in $d b / d b$ wounds (Figure 4C), in accord with our hypothesis that PGT regulates $\mathrm{PGE}_{2}$ homeostasis in wounds. One day after T26A application, $\mathrm{PGE}_{2}$ levels had increased; they reached a stable level at day 13 in diabetic wounds, twofold the level of that of vehicle-treated wounds (Figure 4C) and similar to the levels observed in untreated WT wounds. These data support a model in which PGT expression levels in diabetic wounds limit $\mathrm{PGE}_{2}$ concentration.

\section{PGT Modulates Wound Healing Rates in Diabetic Mice}

To further test the idea that hyperactivation of PGT slows wound healing in diabetes, we applied vehicle or T26A to cutaneous wounds created on the dorsum of BKS.CgDock $7^{m}+/+\operatorname{Lepr} r^{d b} / J(d b / d b)$ mice. These mice are a genetic diabetic mouse model. Wound healing in these animals is severely impaired, ${ }^{32-36}$ with defective neovascularization. $^{35,36}$ We selected $d b / d b$ mice that had plasma glucose levels of $>360 \mathrm{mg} / \mathrm{dL}$. The average wound closure time for these mice was 22 days, which is approximately 7 days longer than for WT mice (see Supplemental Figure S2, A and B, at http://ajp.amjpathol.org). T26A topically applied to wounds accelerated wound closure in a dose-dependent manner (Figure 5, A and B). At $2 \mathrm{mmol} / \mathrm{L}$, T26A shortened $d b / d b$ mouse wound closure time to 16 days, similar to untreated WT mice (see Supplemental Figure S2, A and B, at http://ajp.amjpathol. org). The wound closure rates during the four time periods covering the major part of the healing course were higher in T26A-treated wounds than in vehicle-treated wounds (Table 1). To further support the idea that PGT overexpression caused by hyperglycemia is fundamental to deficiency in wound healing, we applied T26A in another model of diabetes, STZ-induced type 1 diabetic mice. Ten weeks after the mice became diabetic, they exhibited significantly delayed wound healing, relative to WT mice (see Supplemental Figure S2, A and B, at http:// ajp.amjpathol.org). As in the $d b / d b$ mice, T26A treatment shortened wound healing time of STZ-induced diabetic

Table 1. Wound Closure Rates of $d b / d b$ Mice Treated with PGT Inhibitor (T26A) or Vehicle

\begin{tabular}{ccr}
\hline \multirow{2}{*}{$\begin{array}{c}\text { Time period } \\
\text { (days) }\end{array}$} & \multicolumn{2}{c}{ Wound closure rate (\%/day) } \\
\cline { 2 - 3 } & Vehicle & \multicolumn{1}{c}{ T26 } \\
\hline $0-2$ & $3.15 \pm 0.29$ & $14.00 \pm 1.28^{*}$ \\
$2-6$ & $3.55 \pm 0.31$ & $7.88 \pm 0.69^{*}$ \\
$6-10$ & $6.72 \pm 0.56$ & $11.46 \pm 1.10^{*}$ \\
$10-14$ & $7.84 \pm 0.62$ & $16.05 \pm 1.33^{*}$ \\
\hline
\end{tabular}

Data are expressed as means $\pm \operatorname{SEM}(n=5$ per group).

${ }^{\star} P<0.05$. 
mice to the same as the wound healing time of WT mice (see Supplemental Figure S2, A and B, at http://ajp. amjpathol.org).

\section{PGT Regulates Epithelialization in Wounds}

Wound closure was judged by re-epithelialization, which can be visualized by immunohistochemical H\&E staining. T26A treatment resulted in accelerated re-epithelialization of wounds in $d b / d b$ mice (Figure $6 A$ ). By day 15 , the T26A-treated wounds completely re-epithelialized over a smooth thin layer of granulation tissue, whereas the vehicle control was only 55\% re-epithelialized (Figure 6A). The improved re-epithelialization was accompanied by increased proliferation, as indicated by BrdU staining (see Supplemental Figure S3, A and B, at http://ajp.amjpathol.org). T26A-treated wounds had sixfold more BrdU-positive cells populated in the re-epithelialized area, compared with vehicle-treated wounds (see Supplemental Figure S3, A and B, at $h$ ttp://ajp.amjpathol.org).

The major contributor to cutaneous epithelialization is dermal epithelial cell migration, which can be recapitulated in vitro by the wound migration assay. PGT is expressed in epithelial cells. ${ }^{37}$ To determine whether PGT regulates epidermal cell migration, we conducted in vitro wound migration assay with HEKs in euglycemia or hyperglycemia and in the presence or absence of $\mathrm{PGE}_{2}$ or T26. In euglycemia, 34\% of the gap had closed 12 hours after gap creation. $\mathrm{PGE}_{2}$ and T26A increased gap closure to $51 \%$ and $58 \%$, respectively (Figure $6, \mathrm{~B}$ and $\mathrm{C}$ ). Hyperglycemia hampered HEK migration, reducing gap closure to only $20 \%$. Either T26A or $\mathrm{PGE}_{2}$ completely restored $\mathrm{HEK}$ migration in hyperglycemia.

\section{PGT Regulates Neovascularization in Wounds}

Granulation tissue deposit and re-epithelialization are supported by blood vessels. Formation of new blood vessels (ie, neovascularization) is a critical event in wound healing. Our in vitro migration and capillary formation results (Figures 2 and 3) strongly suggest that PGT regulates neovascularization. We conducted detailed examinations of vessel-forming processes in diabetic wound tissues by staining for CD34 (a marker for vessel formation in formalin-fixed mouse tissues ${ }^{38,39}$ ). At day 5 , CD34-positive cells were present in T26A-treated wounds, whereas minimal immunoreactivity was observed in controls (Figure 7). The maximum number of vessels in T26A-treated wounds was reached at day 10; this maximum was 30\% more than the maximum in vehicle-treated wounds, which was reached at day 15 (Figure 7). Thus, T26A treatment accelerated and increased absolute numbers of vessels formed. At day 10, T26Atreated wounds had sixfold more vessels than did vehicle-treated wounds (Figure 7). Most of the vessels were newly formed vessels distributed at the wound margins. Based on the corrective effects observed for inhibition of PGT, these results indicate that hyperactivation of PGT by hyperglycemia is a main cause of impaired neovascularization in diabetic wounds.

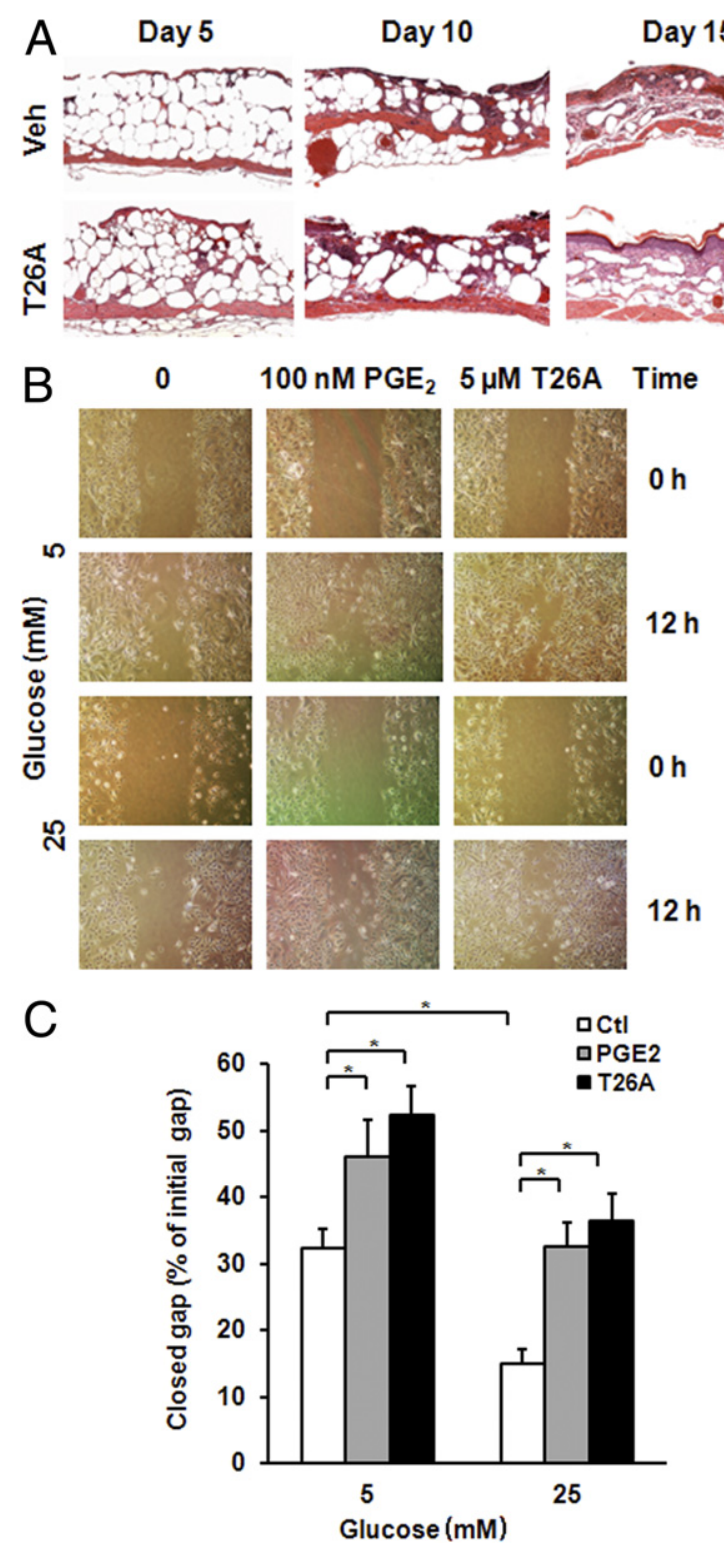

Figure 6. PGT regulates re-epithelialization in wounds. A: Representative photomicrographs of H\&E staining for a pair of wounds of the same $d b / d b$ mice treated with vehicle or $2 \mathrm{mmol} / \mathrm{L} \mathrm{T} 26 \mathrm{~A}$ for 5,10 , and 15 days. Original magnification, $\times 10$. B: Representative photomicrographs of HEK wound migration. HEKs were incubated in medium containing 5 or $25 \mathrm{mmol} / \mathrm{L}$ glucose for 4 days on six-well plates to reach $100 \%$ confluency. Gaps were created in the center of each well. Cells were treated with $100 \mathrm{nmol} / \mathrm{L} \mathrm{PGE}_{2}$ or $5 \mu \mathrm{mol} / \mathrm{L}$ T26A under euglycemic $(5 \mathrm{mmol} / \mathrm{L}$ glucose $)$ or hyperglycemic $(25 \mathrm{mmol} / \mathrm{L}$ glucose) conditions for 12 hours. Original magnfication, $\times 4$. C: HEK gap closure, as percentage of closed gap to the initial gap. Experiments shown in $\mathbf{B}$ were conducted for three rounds, each round in duplicate for each condition. Data are expressed as means $\pm \mathrm{SD}(n=6) .{ }^{*} P<0.05$.

\section{PGT Regulates Blood Flow at Wounds}

To determine whether T26A not only increases the numbers of vessels, but also improves vessel functions, we measured blood flow in 10-mm wounds of $d b / d b$ mice. Significant differences in blood flow between T26A- and vehicle-treated wounds appeared at day 2 (Figure 8A), when the blood flow in T26A-treated wounds was 30\% higher than that in vehicle-treated wounds. In T26Atreated wounds, blood flow reached a peak level be- 
A
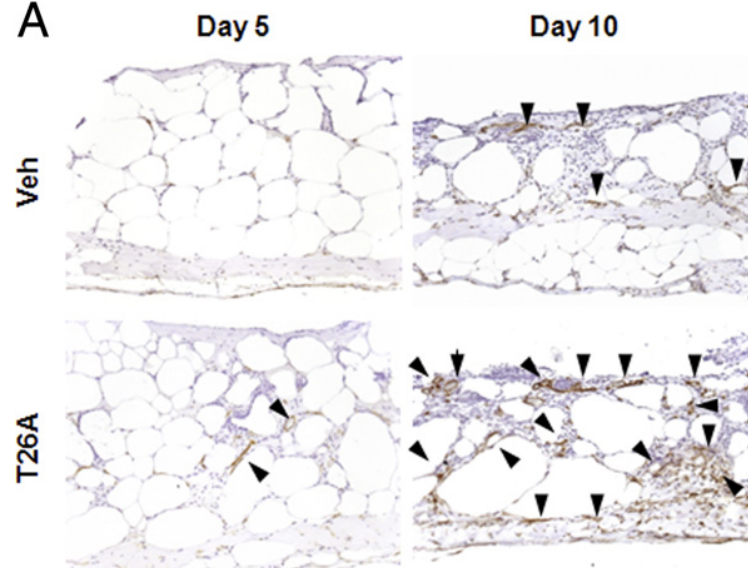
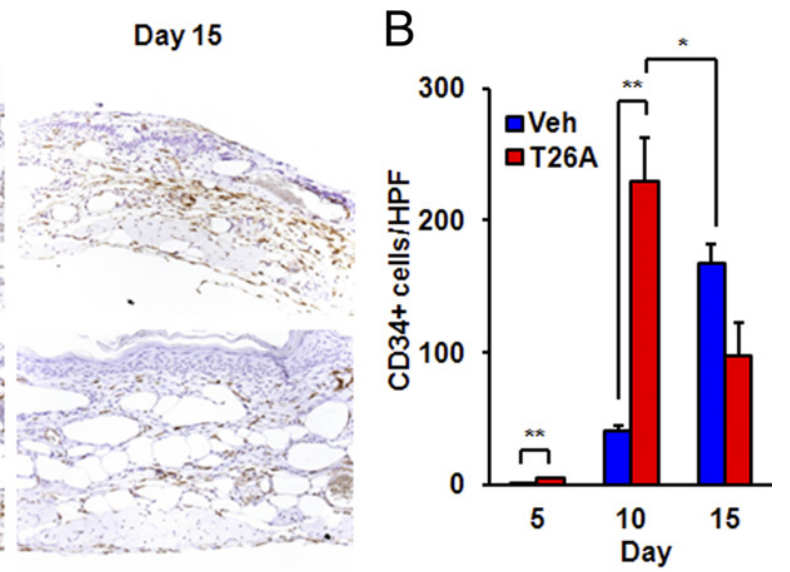

Figure 7. PGT regulates neovascularization in wounds. A: Representative photomicrographs of CD34-positive staining (arrowheads) of a pair of wounds of the same BKS.Cg-Dock $7^{m}+/+L e p r^{d b} / \mathrm{J} d b / d b$ mouse treated with vehicle or T26A for various time periods. Original magnification, $\times 20$. B: Numbers of CD34-positive cells were counted in five random high power fields (HPF) for each mouse tissue. Data are expressed as means \pm SEM $(n=4) . P<0.05$; ${ }^{* *} P<0.01$.

tween day 8 and day 10 , and gradually reduced to normal level as wounds healed (Figure 8B). In vehicletreated wounds, blood flow did not reach a peak level until day 14; however, the maximum blood flow in T26Atreated wounds was $25 \%$ higher than in vehicle-treated wounds (Figure 8B). The effect of T26A on blood flow was in accord with its effects in stimulating neovascularization (Figure 7). These data indicate that PGT inhibition can improve blood flow in wounds, likely as a consequence of PGT inhibition, resulting in increased neovascularization.

\section{Up-Regulated PGT Weakens VEGF Production in Cell Culture and Wound Tissues}

The data we obtained indicating a role of PGT in modulating wound healing and angiogenesis led us to speculate that downstream signaling from $\mathrm{PGE}_{2}$ might be weakened by increased PGT activity. We focused on the most potent and critical stimulator of angiogenesis, VEGF, which is an endothelial cell-specific mitogen ${ }^{20}$ and a known downstream target of $\mathrm{PGE}_{2}{ }^{15-18}$ Inhibition of PGT increased endogenous $\mathrm{PGE}_{2}$ in both HDMECs (Figure 1D) and wounds (Figure 4C), suggesting the possibility that PGT inhibition increases VEGF levels. VEGF protein expression level in HDMECs was very low (Figure 9A). Application of $\mathrm{PGE}_{2}$ increased VEGF levels, as reported previously. ${ }^{16-19}$ Application of T26A, in the absence of exogenous $P \mathrm{PE}_{2}$, increased VEGF, implying that PGT activity modulates VEGF production (Figure 9A). A combination of $P G E_{2}$ and T26A provided additive effects on VEGF protein level (Figure 9A). These effects were mirrored by increases in VEGF mRNA levels with these treatments (Figure 9B). These data are consistent with $P G E_{2}$ levels regulating the strength of signaling that generates VEGF.

To determine whether hyperactivation of PGT causes decreased VEGF accumulation in vivo VEGF protein and mRNA were measured in wounds of WT and $d b / d b$ mice. In WT wounds, VEGF mRNA levels increased to a maximum at day 5 and a maximum protein level around day 7 (Figure 9, C and D). As expected, VEGF protein and
mRNA levels in diabetic wounds were two- to threefold lower, compared with WT wounds, reaching maximum concentrations at day 14 (Figure 9, C and D). To determine whether PGT could be the cause of reduced VEGF accumulation, we inhibited PGT in diabetic wounds and again measured VEGF. Application of T26A led to increased mRNA and protein expression of VEGF, reaching levels similar to those of WT wounds treated with vehicle (Figure 9, C and D). Increases in VEGF mRNA started on day 5 and reached maximum on day 14 (Figure 9D); increases in VEGF protein started on day 7 and reached maximum on day 14 (Figure 9C). The in vitro and in vivo demonstration that inhibition of PGT causes increased VEGF provide evidence that PGT modulates VEGF accumulation in wounds. These data establish PGT as an attractive target for accentuating VEGF signaling in wounds and as a target for improvement of wound healing in diabetic conditions.

\section{Discussion}

Wound healing is a complex process involving several cell types and multiple events, including neovascularization by endothelial cells. ${ }^{40}$ In diabetic wounds, dermal endothelial cells are severely impaired in neovascularization, leading to peripheral ischemia and defective wound healing. ${ }^{41}$ Although defects in molecular signaling contributing to defective neovascularization in diabetic wounds have been investigated extensively, the upstream mediators responsible for downstream defects in this pathological condition remain to be fully clarified. ${ }^{42}$ Here, we report the novel finding that PGT expression and activity are increased in hyperglycemia, and are increased to a greater extent in wounds. We provide evidence that up-regulation of PGT is responsible for the low levels of $\mathrm{PGE}_{2}$ observed in diabetic wounds, as shown by correction of $\mathrm{PGE}_{2}$ levels by application of a potent PGT inhibitor, T26A. ${ }^{25}$

During the course of wound healing, the $\mathrm{PGE}_{2}$ level drops to its lowest level immediately after wounding; it then gradually recovers and reaches a stable level similar 
A
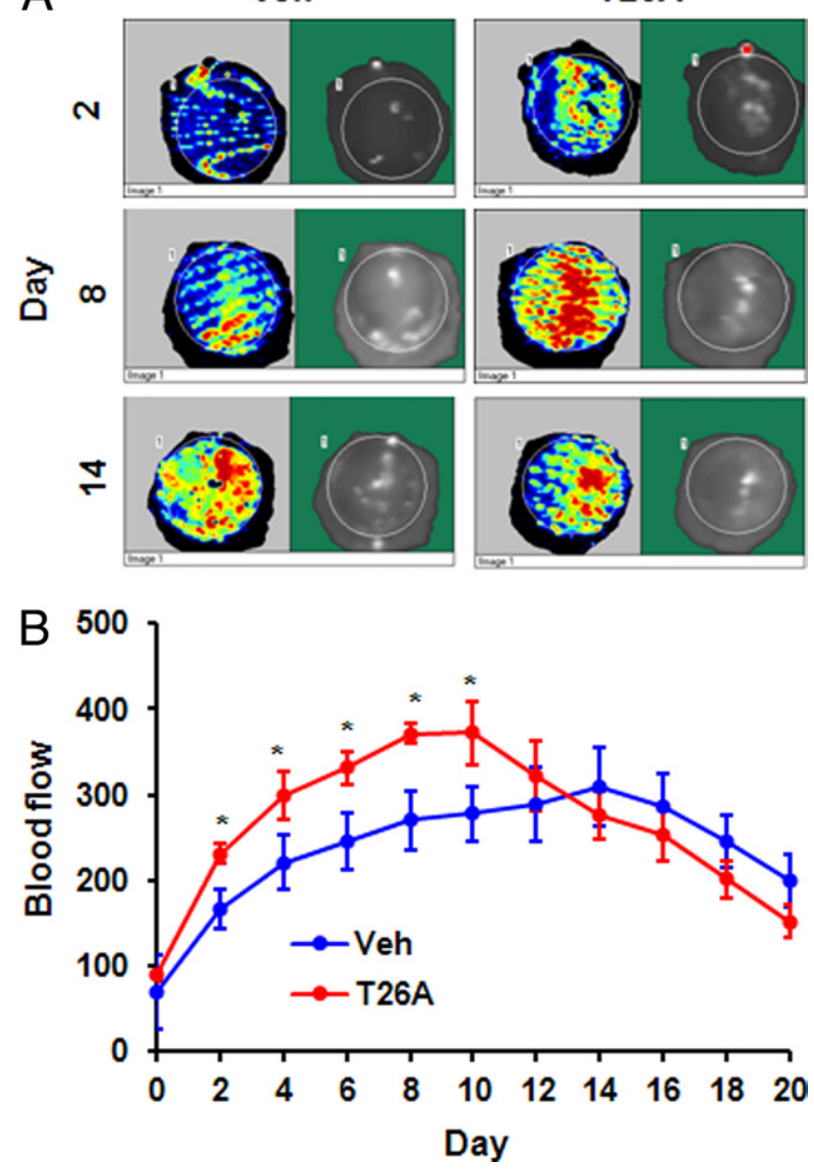

Figure 8. PGT regulates blood flow at wounds. A: Representative images of blood flow in $10-\mathrm{mm}$ wounds on the dorsum of BKS.Cg-Dock $7^{m}+1+$ $L e p r^{d b} / \mathrm{J} d b / d b$ mice treated with vehicle or $2 \mathrm{mmol} / \mathrm{L}$ T26A for 2,8 , and 14 days. One cutaneous wound with $10-\mathrm{mm}$ diameter was created on the dorsum of $d b / d b$ mice. Blood flow in the wound area was measured using a PeriScan PIM 3 imaging system immediately after wounding and every other day, before fresh vehicle or T26A application. B: Analysis of average blood flow in wound during healing as a function of time. Data are expressed as means $\pm \operatorname{SEM}(n=5)$. ${ }^{*} P<0.05$.

to that in intact skin. In contrast, PGT expression increases in the early phase of wound healing up to day 5, and then decreases from the peak level. The steady increase of $\mathrm{PGE}_{2}$ levels in early phases of wounding could be a result of multiple influences, including induction of $\mathrm{PGE}_{2}$ synthases, COX1, COX2, and $\mathrm{PGE}_{2}$ terminal synthases, which could amplify $P \mathrm{PE}_{2}$ production. ${ }^{21}$ Thus, amplification of both synthesis and degradation pathways of prostaglandins appears to be involved in the wound healing process, resolving only as healing occurs. In the late phase of wound healing, PGT levels decline to normal levels again, similar to the resolution of synthase induction as described by others. ${ }^{21}$ Our data nevertheless suggest a powerful role of $P G T$ in regulating the $\mathrm{PGE}_{2}$ concentration that can accumulate in wounds. Induction of PGT in endothelial cells and/or other cell types surrounding endothelial cells in diabetic wounds creates a low-PGE ${ }_{2}$ local environment that surrounds endothelial cells and down-regulates endothelial cell functions. This lowered $\mathrm{PGE}_{2}$ level attenuates $P \mathrm{PE}_{2}$ signaling and is probably involved in down-regulation of VEGF. In fact, we consistently observed that measured blood flow was increased (Figure $8 \mathrm{~B}$ ) when $\mathrm{PGE}_{2}$ levels were increased (Figure 4C), and that blood flow was correlated with VEGF levels (Figure 9C). The best interpretation of these data suggests that $\mathrm{PGT}$ regulates $\mathrm{PGE}_{2}$ directly and VEGF indirectly, and that inhibition of PGT can restore weakened production of VEGF in diabetic wounds.

The importance of PGT expression and activity in wound healing in diabetic animals was further demonstrated in vitro by migration and tube formation assays. We showed that hyperactivation of PGT by hyperglycemia reduces proangiogenic effects of $P G E_{2}$, such as migration and capillary formation. These endothelial cell functions could be restored by inhibition of PGT, indicating a direct connection between PGT hyperactivation in hyperglycemia to angiogenic defects. In addition, we found that PGT plays a direct role in epidermal cell migration. These in vitro results were translated to an in vivo model of wound healing. We showed that PGT levels increase in diabetic wounds, and that $\mathrm{PGE}_{2}$ levels decrease, relative to controls. Application of T26A to diabetic wounds accelerated re-epithelialization, increased proliferation, enhanced neovascularization, promoted blood flow, and ultimately improved wound healing to near WT efficacy. These results were linked to increased $\mathrm{PGE}_{2}$ levels and increased VEGF production in T26Atreated wounds. Our observations suggest that local PGT signaling can be a powerful factor in weakening angiogenesis and vascularization in diabetic wounds. We also provide proof-of-concept evidence that pharmacological inhibition of PGT in wounds can provide corrective effects to these impaired wound healing processes.

$\mathrm{PGE}_{2}$ induces VEGF via several signaling pathways, including CAMP-PKA-CREB, EGFR-ERK $1 / 2,{ }^{43}$ and hypoxia inducible factor- $1 \alpha(\mathrm{HIF}-1 \alpha) .{ }^{44}$ Subbaramaiah et al ${ }^{45}$ showed that suppression of $\mathrm{PGT}$ resulted in enhanced $\mathrm{PGE}_{2}$-CAMP-PKA signaling. We are currently investigating whether $P G T$ regulates VEGF through this signaling pathway. The influence of PGT on HIF- $1 \alpha$ is also being evaluated, given that $\mathrm{HIF}-1 \alpha$ can induce transcription of VEGF. ${ }^{46}$ In fact, sustained HIF- $1 \alpha$ expression improves diabetic wound healing, ${ }^{47,48}$ and $\mathrm{PGE}_{2}$ increases HIF-1 $\alpha$ protein expression. ${ }^{44,49}$ In addition to VEGF, other growth factors play important roles in wound healing, including PDGF and epidermal growth factor (EGF). ${ }^{5,19,50}$ It is possible that PGT modulates those factors, as well.

In the course of wound healing, proliferation and angiogenesis are events that follow inflammation. Initiation and resolution of inflammation is an essential prerequisite for wound healing. ${ }^{50}$ Macrophages play an indispensible role in inflammation. They secrete cytokines and PGs to initiate inflammation and remove neutrophils to resolve inflammation. In diabetic wounds, inflammation is delayed, prolonged, and typically unresolved. $\mathrm{PGE}_{2}$ triggers the initial acute inflammation. ${ }^{11,51-53}$ Notably, $\mathrm{PGE}_{2}$ induces the resolution of inflammation as well, by inducing anti-inflammatory cytokines and proresolution lipid mediators. ${ }^{54,55}$ Drastic induction of PGT in diabetic skin (Figure 4A), causes insufficient initial influx of inflammation mediators such as $\mathrm{PGE}_{2}$ to the environment surrounding macrophages (Figure $4 \mathrm{C}$ ). Inhibition of PGT 
A

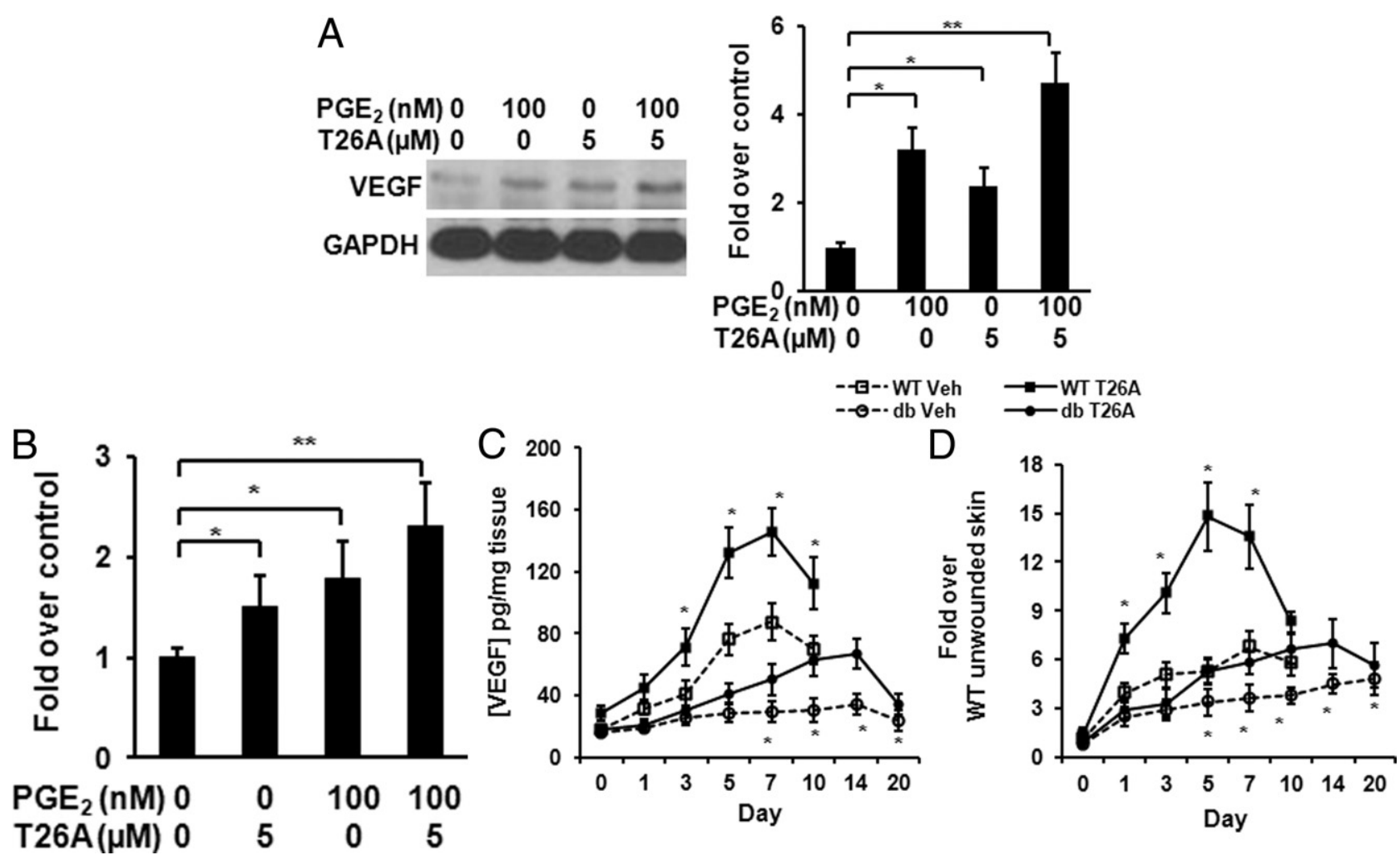

Figure 9. Up-regulated PGT weakens VEGF production in cell culture and wound tissues. A: Representative Western blot of VEGF protein extracted from HDMECs treated with indicated agents for 18 hours. B: VEGF mRNA in HDMECs treated with various concentrations of PGE 2 and/or T26A for 18 hours. These experiments were conducted for three rounds, each round in duplicate for each condition. $\mathbf{C}$ and $\mathbf{D}$ : Levels of VEGF protein $(\mathbf{C})$ and mRNA (D) in mouse wound tissues as a function of time. Two 5-mm cutaneous wounds were created on opposite sides of the dorsum; $15 \mu \mathrm{L}$ of vehicle ( $\%$ Kolliphor EL $+2 \%$ DMSO in water) was applied to one wound and $2 \mathrm{mmol} / \mathrm{L}$ T26A was applied to the other immediately after wounding and every other day thereafter. At various time points $(0$ to 20 days), wound tissues were collected for measurement of VEGF protein $(\mathbf{C})$ and mRNA (D), which were assayed three times for each wound tissue. Data are expressed as means $\pm \mathrm{SD}(n=6)(\mathbf{A}$ and $\mathbf{D})$ or as means \pm SEM $(n=4$ mice per time point $)(\mathbf{C}$ and $\mathbf{D}) .{ }^{*} P<0.05 ;{ }^{* *} P<0.01$.

maintained $\mathrm{PGE}_{2}$ at the wound site, mounting sufficient inflammation and subsequently removing neutrophils in a timely manner, because there were fewer neutrophils in T26A-treated wounds starting from day 3 (data not shown). This information leads to the hypothesis (currently under investigation in our laboratory) that PGT regulates inflammation in wound healing. Proper progression and resolution of inflammation are critical for setting the healing process on the right track, because of the great influence of inflammation on processes such as proliferation and angiogenesis. The observation that T26A-accelerated wound closure was greater during the first 2 days (Figure 5B) strongly suggests that inhibition of PGT corrected delayed onset of inflammation in diabetic wounds, which might have a positive effect on angiogenesis. In other words, the enhanced angiogenesis in T26Atreated wounds is possibly a combined result of direct stimulation of angiogenesis by T26A and indirect enhancement of angiogenesis secondary to corrected inflammation.

Another major event in wound healing is remodeling, in which fibrosis is an important issue because excessive fibrosis increases wound scarring. $P \mathrm{GE}_{2}$ has been shown to decrease fibroblast proliferation, inhibit collagen synthesis, and enhance the expression of matrix metalloproteinases. ${ }^{56}$ Suppressed COX2 and $\mathrm{PGE}_{2}$ mediate the amplification of fibrosis. ${ }^{57}$ As a regulator of $P G E_{2}, P G T$ is predicted to modulate fibrosis (and thereby also remodeling) in cutaneous wound healing. It is conceivable that elevating $\mathrm{PGE}_{2}$ levels in wounds by inhibiting PGT will reduce fibrosis and reduce scarring.

$\mathrm{PGE}_{2}$ is the most abundant $\mathrm{PG}$, but other prostanoids (including $\mathrm{PGH}_{2}, \mathrm{PGD}_{2}$, and $\mathrm{PGF}_{2 \alpha}$ ) are also substrates of PGT. 58,59 These prostanoids are local lipid mediators that trigger a vast array of biological signaling, including inflammation and angiogenesis. The intensity of these signals depends on PG concentration at the cell surface receptors. The amount of an intact PG is a net result of its synthesis and its degradation. PG synthases (eg, COX1 and COX2) have drawn great attention for more than two decades. Only recently has PG catabolism been appreciated as having an important role in controlling signaling, even though rapid clearance of PGs was reported as early as the 1960 s. ${ }^{56}$ The half-life of most PGs is only 1 to 5 minutes. ${ }^{60,61}$ In a series of publications, we have reported that pharmacologically added exogenous $\mathrm{PGE}_{2}$ at concentrations 100-fold higher than endogenous $\mathrm{PGE}_{2}$ (100 to $400 \mathrm{pmol} / \mathrm{L}$ ) can be taken up into cells by PGT and subsequently degraded within 10 minutes. ${ }^{25,26}$ More importantly, the rapid catabolism of exogenous $\mathrm{PGE}_{2}$ occurs in vivo. Intravenously injected $\mathrm{PGE}_{2}$ via jugular vein is mostly degraded within 10 minutes. ${ }^{25}$ Evidently, the PG physical catabolic system is highly efficient. Unless the catabolism is shut down, the effects of exoge- 
nous $\mathrm{PGE}_{2}$ are unsustainable. This is probably why the effects of T26A on cell migration and tube formation were greater than those of $\mathrm{PGE}_{2}$ (Figures 2, 3, and 6). Arguably, maintaining or increasing accumulation of endogenous $\mathrm{PGE}_{2}$ by blocking its catabolism is a superior strategy, compared with direct application of $\mathrm{PGE}_{2}$. This strategy is more effective in a situation in which PG synthesis is unchanged but PG catabolism is up-regulated. In case of diabetic cutaneous wounds, $\mathrm{PGE}_{2}$ levels are low, whereas $\mathrm{PGE}_{2}$ synthases are either unchanged or slightly increased. ${ }^{22}$ Here we show, for the first time, that it is the hyperglycemia-enhanced, PGT-mediated $\mathrm{PGE}_{2}$ uptake (which is the rate-limiting step in $\mathrm{PGE}_{2}$ catabolism) that causes low $\mathrm{PGE}_{2}$ in cultured cells exposed to high glucose and in diabetic mouse skin. Conceivably, blocking PGT can effectively retain $\mathrm{PGE}_{2}$ in cell culture and in wounds (Figures 1D and 4 C).

Because of the instability of prostanoids, many analogs of PGs have been developed for clinical applications. Clinical administration of $\mathrm{PGE}_{2}$ and $\mathrm{PGI}_{2}$ analogs (eg, misoprostol, enprostil, iloprost, and beraprost sodium), has been used to treat patients with diabetic neuropathy and foot ulcer. ${ }^{62-65}$ Those PG analogs are administered systemically, however, and thus have greater potential to cause undesirable side effects than do locally administered drugs. They also have limited efficacy in patients with DFU, ${ }^{66}$ and so are not typically used to treat DFU. The most common clinically used drug treatment is platelet-derived growth factor (PDFG) formulated as becaplermin (trade name: Regranex). ${ }^{5}$ Unfortunately, a considerable proportion of patients do not improve with use of this drug. Furthermore, the becaplermin has an FDA black box warning, because of increased risk of cancer (http://www.fda.gov/NewsEvents/Newsroom/ PressAnnouncements/2008/ucm116909.htm, last accessed March 13, 2012). Inhibition of PGT could provide a distinctly new approach to achieve strengthened PG signaling in wounds. This approach amplifies signal strengths of endogenous $\mathrm{PGE}_{2}$, as well as VEGF; furthermore, no apparent side effects of the inhibitor T26A were detected.

In summary, this report provides evidence that PGT expression and activity are increased by wounding and by hyperglycemia. PGT up-regulation is fundamental to reduced abundance of the angiogenic factors $\mathrm{PGE}_{2}$ and VEGF, as shown by correction by pharmacological inhibition of PGT. These data provide compelling evidence that up-regulated PGT expression and activity could be fundamental to the weakened wound healing responses observed in diabetic patients and thus could be targeted for inhibition as a new DFU therapy.

\section{References}

1. Pecoraro RE, Reiber GE, Burgess EM: Pathways to diabetic limb amputation. Basis for prevention. Diabetes Care 1990, 13:513-521

2. Jeffcoate W, Bakker K: World Diabetes Day: footing the bill. Lancet 2005, 365:1527

3. Cheer K, Shearman C, Jude EB: Managing complications of the diabetic foot. BMJ 2009, 339:b4905
4. Caputo GM, Cavanagh PR, Ulbrecht JS, Gibbons GW, Karchmer AW Assessment and management of foot disease in patients with diabetes. N Engl J Med 1994, 331:854-860

5. White R, McIntosh C: A review of the literature on topical therapies for diabetic foot ulcers. Part 2: Advanced treatments. J Wound Care 2009, 18:335-341

6. Rissanen TT, Vajanto I, Ylä-Herttuala S: Gene therapy for therapeutic angiogenesis in critically ischemic lower limb - On the way to the clinic. Eur J Clin Invest 2001, 31:651-666

7. Dalla Paola L, Faglia E: Treatment of diabetic foot ulcer: an overview strategies for clinical approach. Curr Diabetes Rev 2006, 2:431-447

8. Frykberg RG: Diabetic foot ulcers: pathogenesis and management Am Fam Physician 2002, 66:1655-1662

9. Teixeira AS, Andrade SP: Glucose-induced inhibition of angiogenesis in the rat sponge granuloma is prevented by aminoguanidine. Life Sci 1999, 64:655-662

10. Zachary I, Gliki G: Signaling transduction mechanisms mediating biological actions of the vascular endothelial growth factor family. Cardiovasc Res 2001, 49:568-581

11. Weeks JR: Prostaglandins. Annu Rev Pharmacol 1972, 12:317-336

12. Neisius U, Olsson R, Rukwied R, Lischetzki G, Schmelz M: Prostaglandin E2 induces vasodilation and pruritus, but no protein extravasation in atopic dermatitis and controls. J Am Acad Dermatol 2002, 47:28-32

13. Carter J, Reynoldson JA, Thorburn GD: The effects of certain vasodilating prostaglandins on the coronary and hindlimb vascular beds of the conscious sheep. Comp Biochem Physiol C: 1986, 83:401-406

14. Holzer P, Jocic M, Peskar BA: Mediation by prostaglandins of the nitric oxide-induced neurogenic vasodilatation in rat skin. Br J Pharmacol 1995, 116:2365-2370

15. Ding YB, Shi RH, Tong JD, Li XY, Zhang GX, Xiao WM, Yang JG, Bao Y, Wu J, Yan ZG, Wang XH: PGE2 up-regulates vascular endothelial growth factor expression in MKN28 gastric cancer cells via epidermal growth factor receptor signaling system. Exp Oncol 2005, 27:108113

16. Hatazawa R, Tanaka A, Tanigami M, Amagase K, Kato S, Ashida Y, Takeuchi K: Cyclooxygenase-2/prostaglandin E2 accelerates the healing of gastric ulcers via EP4 receptors. Am J Physiol Gastrointest Liver Physiol 2007, 293:G788-G797

17. Spinella F, Rosanò L, Elia G, Di Castro V, Natali PG, Bagnato A: Endothelin-1-induced prostaglandin E2-EP2, EP4 signaling regulates vascular endothelial growth factor production and ovarian carcinoma cell invasion. J Biol Chem 2004, 279:46700-46705

18. Ben-Av P, Crofford LJ, Wilder RL, Hla T: Induction of vascular endothelial growth factor expression in synovial fibroblasts by prostaglandin $E$ and interleukin-1: a potential mechanism for inflammatory angiogenesis. FEBS Lett 1995, 372:83-87

19. Werner S, Grose R: Regulation of wound healing by growth factors and cytokines. Physiol Rev 2003, 83:835-870

20. Pandya NM, Dhalla NS, Santani DD: Angiogenesis-a new target for future therapy. Vascul Pharmacol 2006, 44:265-274

21. Kämpfer H, Bräutigam L, Geisslinger G, Pfeilschifter J, Frank S: Cyclooxygenase-1-coupled prostaglandin biosynthesis constitutes an essential prerequisite for skin repair. J Invest Dermatol 2003, 120:880-890

22. Kämpfer H, Schmidt R, Geisslinger G, Pfeilschifter J, Frank S: Wound inflammation in diabetic ob/ob mice functional coupling of prostaglandin biosynthesis to cyclooxygenase-1 activity in diabetes-impaired wound healing. Diabetes 2005, 54:1543-1551

23. Nomura T, Lu R, Pucci ML, Schuster VL: The two-step model of prostaglandin signal termination: in vitro reconstitution with the prostaglandin transporter and prostaglandin 15 dehydrogenase. Mol Pharmacol 2004, 65:973-978

24. Chang HY, Locker J, Lu R, Schuster VL: Failure of postnatal ductus arteriosus closure in prostaglandin transporter-deficient mice. Circulation 2010, 121:529-536

25. Chi Y, Khersonsky SM, Chang Y-T, Schuster VL: Identification of a new class of prostaglandin transporter inhibitors and characterization of their biological effects on prostaglandin $E_{2}$ transport. J Pharmacol Exp Ther 2006, 316:1346-1350

26. Chi Y, Min J, Jasmin JF, Lisanti MP, Chang YT, Schuster VL: Development of a high-affinity inhibitor of prostaglandin transporter. J Pharmacol Exp Ther 2011, 349:633-641 
27. Rao R, Redha R, Macias-Perez I, Su Y, Hao C, Zent R, Breyer MD, Pozzi A: Prostaglandin E2-EP4 receptor promotes endothelial cell migration via ERK activation and angiogenesis in vivo. J Biol Chem 2007, 282:16959-16968

28. Nakatsu MN, Davis J, Hughes CC: Optimized fibrin gel bead assay for the study of angiogenesis. J Vis Exp 2007, (3):186

29. Galiano RD, Michaels J 5th, Dobryansky M, Levine JP, Gurtner GC: Quantitative and reproducible murine model of excisional wound healing. Wound Repair Regen 2004, 12:485-492

30. Jain M, LoGerfo FW, Guthrie P, Pradhan L: Effect of hyperglycemia and neuropeptides on interleukin-8 expression and angiogenesis in dermal microvascular endothelial cells. J Vasc Surg 2011, 53:16541660.e2

31. Tsujii M, Kawano S, Tsuji S, Sawaoka H, Hori M, DuBois RN: Cyclooxygenase regulates angiogenesis induced by colon cancer cells [Erratum appeared in Cell 1998, 94: following 271]. Cell 1998, 93: 705-716

32. Thangarajah $H$, Yao D, Chang El, Shi Y, Jazayeri L, Vial IN, Galiano RD, Du XL, Grogan R, Galvez MG, Januszyk M, Brownlee M, Gurtner GC: The molecular basis for impaired hypoxia-induced VEGF expression in diabetic tissues. Proc Natl Acad Sci USA 2009, 106:1350513510

33. Ansel JC, Tiesman JP, Olerud JE, Krueger JG, Krane JF, Tara DC, Shipley GD, Gilbertson D, Usui ML, Hart CE: Human keratinocytes are a major source of cutaneous platelet-derived growth factor. J Clin Invest 1993, 92:671-678

34. Scherer SS, Pietramaggiori G, Mathews JC, Orgill DP: Short periodic applications of the vacuum-assisted closure device cause an extended tissue response in the diabetic mouse model. Plast Reconstr Surg 2009, 124:1458-1465

35. Galeano M, Bitto A, Altavilla D, Minutoli L, Polito F, Calò M, Lo Cascio P, Stagno D'Alcontres F, Squadrito F: Polydeoxyribonucleotide stimulates angiogenesis and wound healing in the genetically diabetic mouse. Wound Repair Regen 2008, 16:208-217

36. Scherer SS, Pietramaggiori G, Matthews J, Perry S, Assmann A, Carothers A, Demcheva M, Muise-Helmericks RC, Seth A, Vournakis JN, Valeri RC, Fischer TH, Hechtman HB, Orgill DP: Poly-N-acetyl glucosamine nanofibers: a new bioactive material to enhance diabetic wound healing by cell migration and angiogenesis [Erratum appeared in Ann Surg 2009, 250:661]. Ann Surg 2009, 250:322-330

37. Lu R, Schuster VL: Molecular cloning of the gene for the human prostaglandin transporter hPGT: gene organization, promoter activity, and chromosomal localization. Biochem Biophys Res Commun 1998, 246:805-812

38. Pedroso DC, Tellechea A, Moura L, Fidalgo-Carvalho I, Duarte J, Carvalho E, Ferreira L: Improved survival, vascular differentiation and wound healing potential of stem cells co-cultured with endothelial cells. PLoS One 2011, 6:e16114

39. Graham CH, Rivers J, Kerbel RS, Stankiewicz KS, White WL: Extent of vascularization as a prognostic indicator in thin $(<0.76 \mathrm{~mm}) \mathrm{malig}$ nant melanomas. Am J Pathol 1994, 145:510-514

40. Singer AJ, Clark RA: Cutaneous wound healing. N Engl J Med 1999, 341:738-746

41. Brem H, Jacobs T, Vileikyte L, Weinberger S, Gibber M, Gill K, Tarnovskaya A, Entero $\mathrm{H}$, Boulton AJ: Wound-healing protocols for diabetic foot and pressure ulcers. Surg Technol Int 2003, 11:85-92

42. Blakytny R, Jude EB: Altered molecular mechanisms of diabetic foot ulcers. Int J Low Extrem Wounds 2009, 8:95-104

43. Ansari KM, Rundhaug JE, Fischer SM: Multiple signaling pathways are responsible for prostaglandin E2-induced murine keratinocyte proliferation. Mol Cancer Res 2008, 6:1003-1016

44. Fukuda R, Kelly B, Semenza GL: Vascular endothelial growth factor gene expression in colon cancer cells exposed to prostaglandin E2 is mediated by hypoxia-inducible factor 1. Cancer Res 2003, 63:23302334

45. Subbaramaiah K, Hudis CA, Dannenberg AJ: The prostaglandin transporter regulates adipogenesis and aromatase transcription. Cancer Prev Res (Phila) 2011, 4:194-206
46. Forsythe JA, Jiang BH, lyer NV, Agani F, Leung SW, Koos RD, Semenza GL: Activation of vascular endothelial growth factor gene transcription by hypoxia-inducible factor 1. Mol Cell Biol 1996, 16: 4604-4613

47. Mace KA, Yu DH, Paydar KZ, Boudreau N, Young DM: Sustained expression of Hif-1alpha in the diabetic environment promotes angiogenesis and cutaneous wound repair. Wound Repair Regen 2007, 15:636-645

48. Botusan IR, Sunkari VG, Savu O, Catrina AI, Grünler J, Lindberg S, Pereira T, Ylä-Herttuala S, Poellinger L, Brismar K, Catrina SB: Stabilization of HIF-1alpha is critical to improve wound healing in diabetic mice. Proc Natl Acad Sci USA 2008, 105:19426-19431

49. Ji R, Chou CL, Xu W, Chen XB, Woodward DF, Regan JW: EP1 prostanoid receptor coupling to $\mathrm{G}$ i/o up-regulates the expression of hypoxia-inducible factor-1 alpha through activation of a phosphoinositide-3 kinase signaling pathway. Mol Pharmacol 2010, 77:10251036

50. Brem H, Tomic-Canic M: Cellular and molecular basis of wound healing in diabetes. J Clin Invest 2007, 117:1219-1222

51. Vane JR: Prostaglandins as mediators of inflammation. Adv Prostaglandin Thromboxane Res 1976, 2:791-801

52. Bonta IL, Parnham MJ: Prostaglandins and chronic inflammation. Biochem Pharmacol 1978, 27:1611-1623

53. Kuehl FA Jr, Egan RW: Prostaglandins, arachidonic acid, and inflammation. Science 1980, 210:978-984

54. Treffkorn L, Scheibe R, Maruyama T, Dieter P: PGE2 exerts its effect on the LPS-induced release of TNF-alpha, ET-1, IL-1alpha, IL-6 and $\mathrm{IL}-10$ via the EP2 and EP4 receptor in rat liver macrophages. Prostaglandins Other Lipid Mediat 2004, 74:113-123

55. Levy BD, Clish CB, Schmidt B, Gronert K, Serhan CN: Lipid mediator class switching during acute inflammation: signals in resolution. Nat Immunol 2001, 2:612-619

56. Su WH, Cheng MH, Lee WL, Tsou TS, Chang WH, Chen CS, Wang $\mathrm{PH}$ : Nonsteroidal anti-inflammatory drugs for wounds: pain relief or excessive scar formation? Mediators Inflamm 2010, 2010:413238

57. Liu F, Mih JD, Shea BS, Kho AT, Sharif AS, Tager AM, Tschumperlin DJ: Feedback amplification of fibrosis through matrix stiffening and COX-2 suppression. J Cell Biol 2010, 190:693-706

58. Chi $Y$, Schuster VL: The prostaglandin transporter PGT transports PGH(2). Biochem Biophys Res Commun 2010, 395:168-172

59. Itoh S, Lu R, Bao Y, Morrow JD, Roberts LJ, Schuster VL: Structural determinants of substrates for the prostaglandin transporter PGT. Mol Pharmacol 1996, 50:738-742

60. Ferreira SH, Vane JR: Prostaglandins: their disappearance from and release into the circulation. Nature 1967, 216:868-873

61. Hamberg M, Samuelsson B: On the catabolism of prostaglandins E 1 and E 2 in man. J Biol Chem 1971, 246:6713-6721

62. Mirenda F, La Spada M, Baccellieri D, Stilo F, Benedetto F, Spinelli F: lloprost infusion in diabetic patients with peripheral arterial occlusive disease and foot ulcers. Chir Ital 2005, 57:731-735

63. Okuda Y, Sone H, Mizutani S, Asano M, Tsurushima Y, Ogawa M, Tada K, Asakura Y, Kawakami Y, Suzuki S, Yamashita K: Acute effect of beraprost sodium on lower limb circulation in patients with noninsulin-dependent diabetes mellitus-evaluation by color Doppler ultrasonography and laser cutaneous blood flowmetry. Prostaglandins 1996, 52:375-384

64. Ueno $Y$, Yamada N, Koike H, Nishio S: Effects of beraprost sodium and prostaglandin E1 on skin blood flow in diabetic rats and normal dogs. Gen Pharmacol 1996, 27:333-335

65. Ueno Y, Koike H, Nakamura Y, Ochi Y, Annoh S, Nishio S: Effects of beraprost sodium, a prostacyclin analogue, on diabetic neuropathy in streptozotocin-induced diabetic rats. Jpn J Pharmacol 1996, 70:177182

66. Brass EP, Anthony R, Dormandy J, Hiatt WR, Jiao J, Nakanishi A McNamara T, Nehler M; Circulase investigators: Parenteral therapy with lipo-ecraprost, a lipid-based formulation of a PGE1 analog, does not alter six-month outcomes in patients with critical leg ischemia. $J$ Vasc Surg 2006, 43:752-759 